\title{
Effects of Exposure to Dietary Chromium on Tissue Mineral Contents in Rats Fed Diets with Fiber
}

\author{
Anna Prescha • Monika Krzysik • Katarzyna Zabłocka-Słowińska • \\ Halina Grajeta
}

Received: 7 January 2014 / Accepted: 8 April 2014 /Published online: 22 April 2014

(C) The Author(s) 2014. This article is published with open access at Springerlink.com

\begin{abstract}
This study evaluated the effects of diets with fiber (cellulose and/or pectin) supplemented with chromium(III) on homeostasis of selected minerals in femurs, thigh muscles, livers, and kidneys of rats. For 6 weeks, male rats were fed experimental diets: a fiber-free diet (FF), a diet containing $5 \%$ cellulose (CEL), $5 \%$ pectin (PEC), or $2.5 \%$ cellulose and $2.5 \%$ pectin $(\mathrm{CEL}+\mathrm{PEC})$. These diets had 2.53 or $0.164 \mathrm{mg} \mathrm{Cr} / \mathrm{kg}$ diet. The tissue levels of $\mathrm{Ca}, \mathrm{Mg}, \mathrm{Zn}, \mathrm{Fe}$, and $\mathrm{Cr}$ were determined by using atomic absorption spectrometry. Supplementing diets with $\mathrm{Cr}$ resulted in significantly higher $\mathrm{Cr}$ levels in the femurs of rats fed the CEL diet and significantly higher $\mathrm{Cr}$ and $\mathrm{Fe}$ levels in the rats fed the CEL+PEC diet compared to the rats fed FF diet. Muscle Ca content was significantly lower in the rats fed the $\mathrm{CEL}+\mathrm{PEC}+\mathrm{Cr}$ diet compared to the rats fed $\mathrm{FF}+\mathrm{Cr}$ diet. The rats consuming the $\mathrm{PEC}+\mathrm{Cr}$ diet had the highest liver $\mathrm{Cr}$ content. The highest kidney $\mathrm{Zn}$ content was observed in the rats fed diets containing $\mathrm{Cr}$ and one type of fiber. These results indicate that diets containing chromium at elevated dose and fiber have a significant effect on the mineral balance in rat tissues.
\end{abstract}

Keywords Cellulose $\cdot$ Pectin $\cdot$ Chromium $\cdot$ Calcium · Magnesium $\cdot$ Iron $\cdot$ Zinc $\cdot$ Rats

\section{Introduction}

Chromium in its trivalent form, $\mathrm{Cr}(\mathrm{III})$, is generally regarded as an essential nutrient that regulates carbohydrate, lipid, and protein metabolism by enhancing insulin action [1, 2]. $\mathrm{Cr}$ (III) exhibits low toxicity in animals, which may result from its poor transport across cellular membranes [3]. However, there are

A. Prescha $(\bowtie) \cdot$ M. Krzysik $\cdot$ K. Zabłocka-Słowińska $\cdot$ H. Grajeta

Department of Food Science and Dietetics, Wroclaw Medical

University, Borowska 211, 50-556 Wroclaw, Poland

e-mail: anna.prescha@umed.wroc.pl relatively few articles on the effect of $\mathrm{Cr}$ supplementation on the concentration of $\mathrm{Cr}$ and other minerals in animal tissues [4-8]. Studies of the distribution of $\mathrm{Cr}$ in the tissues of rats indicate that $\mathrm{Cr}$ content is greatest in the kidneys. $\mathrm{Cr}$ supplementation may also be associated with increased $\mathrm{Cr}$ content in the liver, bones, and ovaries. The effects of $\mathrm{Cr}$ on tissue mineral concentration show that it has the most significant interaction with Fe [4, 5, 9].

Soluble fiber (pentosans, pectin, gums, and mucilage) performs important physiological functions, e.g., reduces cholesterol level and blood pressure, prevents gastrointestinal problems, protects against the onset of several cancers, and increases mineral bioavailability [10]. The principal potential health benefits of insoluble fibers (cellulose, hemicellulose, and lignin) are related to gastrointestinal transit and constipation. Prospective cohort studies indicate that diets high in insoluble cereal dietary fiber and whole grains might reduce diabetes risk [11]. The relationship between dietary fiber and $\mathrm{Ca}, \mathrm{Mg}, \mathrm{Zn}, \mathrm{Mn}$, $\mathrm{Cu}$, and $\mathrm{Fe}$ absorption and balance is controversial, however, with some studies reporting impaired mineral absorption or balance $[12,13]$ and other studies reporting no change [14] or a positive balance with a high-fiber diet [15-17].

The influence of $\mathrm{Cr}$, when administered in a diet with soluble or insoluble fiber, on the distribution of minerals in the tissues of rats has not been assessed. The present study was undertaken to determine whether diets with cellulose and/or pectin and elevated $\mathrm{Cr}$ amount have an interactive effect on the $\mathrm{Cr}, \mathrm{Ca}, \mathrm{Mg}, \mathrm{Zn}$, and $\mathrm{Fe}$ content in the tissues of rats.

\section{Materials and Methods}

Experimental Design

The study was performed on 80 male Buffalo rats (mean initial bodyweight $120 \pm 10 \mathrm{~g}$ ) that were divided into eight groups 
(ten rats per group, five rats per cage). The rats were housed in standard polypropylene cages with stainless steel wire lids. For 6 weeks, they were fed the following experimental diets: group 1 -a fiber-free diet (FF); group 2-a fiber-free diet with chromium $(\mathrm{FF}+\mathrm{Cr})$; group 3-a diet with $5 \%$ cellulose (CEL); group 4-a diet with $5 \%$ cellulose and chromium $(\mathrm{CEL}+\mathrm{Cr})$; group 5 - a diet with $5 \%$ pectin (PEC); group $6-$ a diet with $5 \%$ pectin and chromium $(\mathrm{PEC}+\mathrm{Cr})$; group $7-\mathrm{a}$ diet with $2.5 \%$ cellulose and $2.5 \%$ pectin (CEL+PEC); and group 8 -a diet with $2.5 \%$ cellulose, $2.5 \%$ pectin, and chromium $(\mathrm{CEL}+\mathrm{PEC}+\mathrm{Cr})$ (Table 1). AIN-93 M diets enriched with fat were applied in the study [18]. The following diet modifications were made: fat content was increased from 40 to $100 \mathrm{~g} / \mathrm{kg}$ diet, $90 \%$ of fat was replaced by lard, and cholesterol was added at the level of $2 \mathrm{~g} / \mathrm{kg}$ diet. The design of the experiment included research on other purposes, i.e., the influence of type of diet on lipid and carbohydrate metabolism [19]. However, the impact of the increased fat content on mineral levels in rat tissue was not studied. $\mathrm{Cr}$ was added to the diet with a $0.37 \mathrm{~g} \mathrm{CrCl}_{3} \cdot 6 \mathrm{H}_{2} \mathrm{O} / \mathrm{kg}$ mineral mix, yielding a dietary $\mathrm{Cr}$ content of $2.53 \mathrm{mg} \mathrm{Cr}(\mathrm{III}) / \mathrm{kg}$ diet. The analytically determined $\mathrm{Cr}$ content in low-Cr diets averaged $0.164 \mathrm{mg} / \mathrm{kg}$ diet. The apple pectin WEJ-3 F (Pektowin, Jaslo, Poland) and $\alpha$-cellulose (Sigma-Aldrich, St. Louis, MO, USA; cat. no. C6429) were used. The animals were allowed free access to their food and to distilled water. The rats were kept in cages under a 12-h light cycle at a temperature of $22 \pm 1{ }^{\circ} \mathrm{C}$ and a humidity level of 55-60\%. The study was approved by the First Local Ethics Commission in Wroclaw (approval no. 20/ 2006). The intake of $\mathrm{Cr}$, based on an analytical assessment of the diets, is shown in Table 2. Rat urine was collected according to Juturu et al. [20], and the urinary Cr excretion rate was estimated by comparing the amount of $\mathrm{Cr}$ excreted in the urine to the Cr intake (Table 2). At the end of the experiment, the rats were food-deprived for $24 \mathrm{~h}$ and then anesthetized with Bioketan. Liver, kidney, and thigh muscle samples were collected after the dislocation of the cervical vertebrae, and the femurs were separated and cleaned. All tissues were washed in a cold solution of $0.9 \% \mathrm{NaCl}$, weighed, and then stored at $-20{ }^{\circ} \mathrm{C}$ until analysis.

\section{Determination of Elements in Rat Tissues and Urine}

The samples of tissues and urine $(1.0 \mathrm{~g})$ were mineralized with $\mathrm{HNO}_{3}$ (65\% Suprapur; Merck, Darmstadt, Germany) in the microwave digestion system Plazmatronika (Wroclaw, Poland) according to the producer's recommendations. Digested solutions were diluted with deionized water to $10 \mathrm{ml}$ after removing nitrogen dioxide fumes and cooling. $\mathrm{Ca}, \mathrm{Mg}, \mathrm{Fe}$, and $\mathrm{Zn}$ content was determined by flame atomic absorption

Table 1 The composition of the experimental diets

\begin{tabular}{|c|c|c|c|c|c|c|c|c|}
\hline \multirow[t]{2}{*}{ Components ( $\mathrm{g} / \mathrm{kg}$ diet) } & \multicolumn{8}{|c|}{ Experimental diets ${ }^{\mathrm{a}}$} \\
\hline & $\mathrm{FF}$ & $\mathrm{FF}+\mathrm{Cr}$ & CEL & $\mathrm{CEL}+\mathrm{Cr}$ & PEC & $\mathrm{PEC}+\mathrm{Cr}$ & $\mathrm{CEL}+\mathrm{PEC}$ & $\mathrm{CEL}+\mathrm{PEC}+\mathrm{Cr}$ \\
\hline Wheat starch & 615.7 & 615.7 & 565.7 & 565.7 & 565.7 & 565.7 & 565.7 & 565.7 \\
\hline Casein & 145.0 & 145.0 & 145.0 & 145.0 & 145.0 & 145.0 & 145.0 & 145.0 \\
\hline Sucrose & 88.0 & 88.0 & 88.0 & 88.0 & 88.0 & 88.0 & 88.0 & 88.0 \\
\hline Soybean oil & 10.0 & 10.0 & 10.0 & 10.0 & 10.0 & 10.0 & 10.0 & 10.0 \\
\hline Lard & 90.0 & 90.0 & 90.0 & 90.0 & 90.0 & 90.0 & 90.0 & 90.0 \\
\hline Mineral mixture & 35.0 & $35.0^{\mathrm{b}}$ & 35.0 & $35.0^{\mathrm{b}}$ & 35.0 & $35.0^{\mathrm{b}}$ & 35.0 & $35.0^{\mathrm{b}}$ \\
\hline Vitamin mixture & 10.0 & 10.0 & 10.0 & 10.0 & 10.0 & 10.0 & 10.0 & 10.0 \\
\hline L-cysteine & 1.8 & 1.8 & 1.8 & 1.8 & 1.8 & 1.8 & 1.8 & 1.8 \\
\hline Choline chloride & 2.5 & 2.5 & 2.5 & 2.5 & 2.5 & 2.5 & 2.5 & 2.5 \\
\hline Cholesterol & 2.0 & 2.0 & 2.0 & 2.0 & 2.0 & 2.0 & 2.0 & 2.0 \\
\hline Cellulose & - & - & 50.0 & 50.0 & - & - & 25.0 & 25.0 \\
\hline Pectin & - & - & - & - & 50.0 & 50.0 & 25.0 & 25.0 \\
\hline \multicolumn{9}{|c|}{ Minerals determined in diets (dry mass basis) } \\
\hline $\mathrm{Ca}(\mathrm{mg} / \mathrm{g})$ & 3.9 & 3.8 & 3.8 & 3.8 & 3.6 & 3.2 & 3.4 & 3.8 \\
\hline $\mathrm{Mg}(\mathrm{mg} / \mathrm{g})$ & 0.56 & 0.58 & 0.57 & 0.58 & 0.56 & 0.57 & 0.58 & 0.57 \\
\hline $\mathrm{Zn}(\mu \mathrm{g} / \mathrm{g})$ & 40 & 42 & 39 & 40 & 40 & 41 & 40 & 40 \\
\hline $\mathrm{Fe}(\mu \mathrm{g} / \mathrm{g})$ & 37 & 36 & 38 & 39 & 40 & 40 & 38 & 39 \\
\hline $\mathrm{Cr}(\mu \mathrm{g} / \mathrm{g})$ & 0.13 & 2.33 & 0.13 & 2.21 & 0.21 & 2.59 & 0.13 & 2.30 \\
\hline
\end{tabular}

$F F$ a fiber-free diet, $C E L$ a diet with $5 \%$ cellulose, $P E C$ a diet with $5 \%$ pectin, $C E L+P E C$ a diet with $2.5 \%$ cellulose and $2.5 \%$ pectin

${ }^{\mathrm{a}}$ The diets differ in fiber content and $\mathrm{Cr}$ content

${ }^{\mathrm{b}}$ The mineral mix added to the diets with $\mathrm{Cr}$ contained $0.37 \mathrm{~g} \mathrm{CrCl}_{3} \cdot 6 \mathrm{H}_{2} \mathrm{O} / \mathrm{kg}$ mix $(2.53 \mathrm{mg} \mathrm{Cr} / \mathrm{kg}$ diet, mean value, dry mass basis $)$ 
Table 2 The $\mathrm{Cr}$ intake and minimum absorption of rats in the groups fed experimental diets

\begin{tabular}{|c|c|c|c|c|c|c|c|c|}
\hline & \multicolumn{8}{|c|}{ Experimental diets ${ }^{\mathrm{a}}$} \\
\hline & $\mathrm{FF}$ & $\mathrm{FF}+\mathrm{Cr}$ & CEL & $\mathrm{CEL}+\mathrm{Cr}$ & PEC & $\mathrm{PEC}+\mathrm{Cr}$ & $\mathrm{CEL}+\mathrm{PEC}$ & $\mathrm{CEL}+\mathrm{PEC}+\mathrm{Cr}$ \\
\hline Cr intake ( $\mu \mathrm{g} /$ day $)$ & $1.69 \pm 0.19^{\mathrm{A}}$ & $36.8 \pm 3.16^{\mathrm{B}}$ & $1.99 \pm 0.21^{\mathrm{A}}$ & $34.5 \pm 3.85^{\mathrm{B}}$ & $3.80 \pm 0.63^{\mathrm{A}}$ & $38.3 \pm 1.61^{\mathrm{B}}$ & $1.96 \pm 0.24^{\mathrm{A}}$ & $34.5 \pm 1.63^{\mathrm{B}}$ \\
\hline $\begin{array}{l}\text { Cr excretion in urine } \\
(\mu \mathrm{g} / \text { day }) \times 10^{-2}\end{array}$ & $2.02 \pm 0.23^{\mathrm{A}}$ & $2.60 \pm 0.31^{\mathrm{AB}}$ & $3.59 \pm 0.21^{\mathrm{AB}}$ & $6.83 \pm 0.44^{\mathrm{CDE}}$ & $3.84 \pm 0.39^{\mathrm{ABD}}$ & $7.28 \pm 0.35^{\mathrm{CE}}$ & $5.35 \pm 0.42^{\mathrm{BE}}$ & $8.60 \pm 2.89^{\mathrm{C}}$ \\
\hline $\begin{array}{l}\text { Urinary excretion } \\
\text { rate }(\%)^{\mathrm{b}}\end{array}$ & $1.19 \pm 0.14^{\mathrm{AB}}$ & $0.07 \pm 0.02^{\mathrm{B}}$ & $1.84 \pm 0.50^{\mathrm{AC}}$ & $0.19 \pm 0.08^{\mathrm{BD}}$ & $1.01 \pm 0.74^{\mathrm{ABD}}$ & $0.19 \pm 0.03^{\mathrm{BD}}$ & $2.73 \pm 1.35^{\mathrm{C}}$ & $0.25 \pm 0.06^{\mathrm{BD}}$ \\
\hline
\end{tabular}

The data are presented as the mean \pm SD. The values in the same row that do not share the same superscript letter are significantly different (analysis of variance, $P<0.05$ )

$F F$ a fiber-free diet, $C E L$ a diet with $5 \%$ cellulose, $P E C$ a diet with $5 \%$ pectin, $C E L+P E C$ a diet with $2.5 \%$ cellulose and $2.5 \%$ pectin

${ }^{\mathrm{a}}$ The diets differ in fiber content and $\mathrm{Cr}$ content

${ }^{\mathrm{b}}$ Urinary excretion rate $(\%)=(\mathrm{Cr}$ excreted in rat urine $(\mu \mathrm{g} / \mathrm{day}) / \mathrm{Cr}$ intake $(\mu \mathrm{g} / \mathrm{day})) \times 100 \%$

spectrometry (F-AAS) [21], and Cr content was determined by graphite furnace atomic absorption spectrometry (GFAAS) [22]. The Perkin Elmer Model 3110 (Norwalk, CT, USA) atomic absorption spectrometer was used for measurements. The accuracy and precision were assessed by determining the levels of $\mathrm{Ca}, \mathrm{Mg}, \mathrm{Fe}, \mathrm{Zn}$, and $\mathrm{Cr}$ in the certified reference material (NCS ZC730016 Chicken), which was digested analogously to the samples. The mean recoveries of the certified levels were as follows: $\mathrm{Cr}-87 \%, \mathrm{Ca}-89 \%$, $\mathrm{Mg}-91 \%, \mathrm{Fe}-99 \%$, and $\mathrm{Zn}-101 \%$. The femur P content was also determined spectrophotometrically using Scheel's method [23].

\section{Statistical Analysis}

Data were analyzed using Statistica v. 10.0. An analysis of variance (ANOVA) was performed, followed by Tukey's post hoc test for intergroup comparison of parametric data. When dealing with nonparametric data, the Kruskal-Wallis test was used. A $P$ value less than 0.05 was considered statistically significant.

\section{Results}

The dietary intake and the body mass of the rats did not differ between the groups. The average dietary intake was within the range of $14.6 \pm 1.1$ to $15.8 \pm 1.3 \mathrm{~g} /$ day, and the body mass gains were within the range of $100 \pm 16$ to $119 \pm 28 \mathrm{~g}$. The daily $\mathrm{Cr}$ excretion in urine was significantly higher in rats fed $\mathrm{Cr}$ supplemented diets with fiber than in other groups. However, the urinary $\mathrm{Cr}$ excretion rate was lower in rats that received a Cr-supplemented diet than in the rats that were fed low-Cr diets (Table 2). In rat groups fed fiber-free diets, the amount of excreted $\mathrm{Cr}$ per day did not differ significantly despite the different $\mathrm{Cr}$ intake. Adding cellulose and/or pectin resulted in significantly higher $\mathrm{Cr}$ excretion in rat groups fed $\mathrm{Cr}$ supplemented diets compared to rats fed low-Cr diets.

The mean mineral content in the femurs and thigh muscles of the rats is presented in Table 3. The highest $\mathrm{Cr}$ content was observed in the femurs of the rats that ate the $\mathrm{CEL}+\mathrm{Cr}$ and the $\mathrm{CEL}+\mathrm{PEC}+\mathrm{Cr}$ diets; the lowest $\mathrm{Cr}$ levels were found in the rats fed the fiber-free diet, even if the diet was fortified with $\mathrm{Cr}$. The rats that received the $\mathrm{PEC}+\mathrm{Cr}$ and the $\mathrm{CEL}+\mathrm{PEC}+\mathrm{Cr}$ diets had significantly higher $\mathrm{Fe}$ content in the femur than the $\mathrm{FF}$ and $\mathrm{FF}+\mathrm{Cr}$ groups. The femur $\mathrm{Zn}$ content was significantly higher in the rats fed a FF diet than in the groups fed diets with fiber. The CEL+PEC diet led to a significantly lower level of $\mathrm{P}$ in the femurs of the rats, compared to the FF group. Adding $\mathrm{Cr}$ to the $\mathrm{FF}$ diet and to the diets with fiber did not yield significant differences in the content of $\mathrm{Zn}, \mathrm{Mg}$, or $\mathrm{P}$ in the femur. There were no significant differences in the $\mathrm{Cr}$, $\mathrm{Fe}$, and $\mathrm{Zn}$ concentrations in the muscles between the groups. The rats fed the $\mathrm{CEL}+\mathrm{PEC}+\mathrm{Cr}$ diets had a significantly lower concentration of muscle $\mathrm{Ca}$ compared to the group fed the $\mathrm{FF}+\mathrm{Cr}$ diet. The $\mathrm{CEL}+\mathrm{PEC}+\mathrm{Cr}$ group was also distinguished from the other groups by having the highest muscle $\mathrm{Mg}$ concentration, which was significantly different from the FF group.

Table 4 shows the mean mineral content in the livers and kidneys of the rats. In the group that received the $\mathrm{PEC}+\mathrm{Cr}$ diet, a sixfold to tenfold higher $\mathrm{Cr}$ content was observed in the liver compared to the other groups. The lowest $\mathrm{Ca}, \mathrm{Zn}$, and $\mathrm{Mg}$ content was observed in the livers of the rats fed the PEC diet. The Fe content of the liver did not change significantly following supplementation with cellulose, pectin, and/or Cr. The concentration of $\mathrm{Ca}$ in the kidneys was the highest in the group that ate the CEL diet. The addition of pectin or cellulose to diets, especially with $\mathrm{Cr}$, caused significantly higher $\mathrm{Zn}$ accumulation in this tissue. Higher $\mathrm{Mg}$ content was observed mainly in the groups that received pectin in their diets. The kidney $\mathrm{Cr}$ and Fe concentrations were not altered by any of the diets. 
Table 3 The effects of experimental diets on the mineral content in the femurs and thigh muscles of rats

\begin{tabular}{|c|c|c|c|c|c|c|c|c|}
\hline \multirow[t]{2}{*}{ Mineral } & \multicolumn{8}{|c|}{ Experimental diets $^{\mathrm{a}}$} \\
\hline & $\mathrm{FF}$ & $\mathrm{FF}+\mathrm{Cr}$ & CEL & $\mathrm{CEL}+\mathrm{Cr}$ & PEC & $\mathrm{PEC}+\mathrm{Cr}$ & $\mathrm{CEL}+\mathrm{PEC}$ & $\mathrm{CEL}+\mathrm{PEC}+\mathrm{Cr}$ \\
\hline \multicolumn{9}{|l|}{ Femur } \\
\hline $\mathrm{Cr}(\mu \mathrm{g} / \mathrm{g} \mathrm{WM}) \times 10^{-2}$ & $10.1 \pm 5.3^{\mathrm{A}}$ & $13.0 \pm 6.9^{\mathrm{AB}}$ & $18.4 \pm 8.1^{\mathrm{AB}}$ & $28.3 \pm 10.4^{\mathrm{B}}$ & $15.6 \pm 6.8^{\mathrm{AB}}$ & $17.2 \pm 9.0^{\mathrm{AB}}$ & $20.2 \pm 7.8^{\mathrm{AB}}$ & $24.9 \pm 9.9^{\mathrm{B}}$ \\
\hline $\mathrm{Ca}(\mathrm{mg} / \mathrm{g} \mathrm{WM})$ & $158 \pm 21$ & $143 \pm 23$ & $149 \pm 17$ & $148 \pm 20$ & $141 \pm 14$ & $135 \pm 19$ & $161 \pm 20$ & $141 \pm 22$ \\
\hline $\mathrm{Fe}(\mu \mathrm{g} / \mathrm{g} \mathrm{WM})$ & $59.6 \pm 8.2^{\mathrm{AC}}$ & $59.9 \pm 7.3^{\mathrm{A}}$ & $62.9 \pm 6.8^{\mathrm{AB}}$ & $69.5 \pm 5.0^{\mathrm{AB}}$ & $65.9 \pm 7.6^{\mathrm{AB}}$ & $73.4 \pm 8.7^{\mathrm{BC}}$ & $69.3 \pm 6.3^{\mathrm{AB}}$ & $75.9 \pm 13.1^{\mathrm{B}}$ \\
\hline $\mathrm{Zn}(\mu \mathrm{g} / \mathrm{g} W M)$ & $135 \pm 8^{\mathrm{A}}$ & $133 \pm 7^{\mathrm{AC}}$ & $124 \pm 6^{\mathrm{BC}}$ & $123 \pm 6^{\mathrm{AB}}$ & $123 \pm 7^{\mathrm{B}}$ & $124 \pm 5^{\mathrm{BC}}$ & $121 \pm 7^{\mathrm{B}}$ & $127 \pm 6^{\mathrm{AB}}$ \\
\hline $\mathrm{Mg}(\mathrm{mg} / \mathrm{g} \mathrm{WM})$ & $4.94 \pm 0.86$ & $4.54 \pm 0.79$ & $5.19 \pm 0.99$ & $4.19 \pm 0.86$ & $3.68 \pm 1.02$ & $3.74 \pm 0.83$ & $4.35 \pm 0.93$ & $3.68 \pm 0.75$ \\
\hline $\mathrm{P}(\mathrm{mg} / \mathrm{g} \mathrm{WM})$ & $82.3 \pm 8.2^{\mathrm{AC}}$ & $83.4 \pm 7.2^{\mathrm{A}}$ & $76.6 \pm 9.2^{\mathrm{AB}}$ & $79.2 \pm 6.6^{\mathrm{AB}}$ & $68.1 \pm 9.6^{\mathrm{BC}}$ & $72.4 \pm 4.0^{\mathrm{AB}}$ & $65.9 \pm 8.7^{\mathrm{B}}$ & $76.2 \pm 9.9^{\mathrm{AB}}$ \\
\hline \multicolumn{9}{|l|}{ Muscle } \\
\hline $\mathrm{Cr}(\mu \mathrm{g} / \mathrm{g} \mathrm{WM}) \times 10^{-2}$ & $16.3 \pm 8.9$ & $25.0 \pm 9.6$ & $20.8 \pm 11.7$ & $32.4 \pm 12.8$ & $26.1 \pm 9.0$ & $26.7 \pm 11.0$ & $20.8 \pm 9.8$ & $19.1 \pm 7.9$ \\
\hline $\mathrm{Ca}(\mu \mathrm{g} / \mathrm{g} \mathrm{WM})$ & $85.1 \pm 24.2^{\mathrm{AB}}$ & $126.0 \pm 43.8^{\mathrm{A}}$ & $72.8 \pm 7.6^{\mathrm{AB}}$ & $82.2 \pm 21.8^{\mathrm{AB}}$ & $93.2 \pm 34.3^{\mathrm{AB}}$ & $72.0 \pm 21.9^{\mathrm{AB}}$ & $70.7 \pm 13.6^{\mathrm{AB}}$ & $60.4 \pm 12.9^{\mathrm{B}}$ \\
\hline $\mathrm{Fe}(\mu \mathrm{g} / \mathrm{g} W M)$ & $13.3 \pm 2.5$ & $16.5 \pm 4.7$ & $12.9 \pm 1.6$ & $14.0 \pm 3.4$ & $12.7 \pm 2.8$ & $12.6 \pm 2.0$ & $13.0 \pm 2.1$ & $11.7 \pm 1.2$ \\
\hline $\mathrm{Zn}(\mu \mathrm{g} / \mathrm{g} \mathrm{WM})$ & $11.8 \pm 2.1$ & $12.5 \pm 3.4$ & $9.4 \pm 0.9$ & $11.0 \pm 1.9$ & $10.2 \pm 2.2$ & $10.2 \pm 1.4$ & $10.7 \pm 1.4$ & $9.9 \pm 1.7$ \\
\hline $\mathrm{Mg}(\mu \mathrm{g} / \mathrm{g} W M)$ & $268 \pm 23^{\mathrm{A}}$ & $291 \pm 18^{\mathrm{AB}}$ & $286 \pm 10^{\mathrm{AB}}$ & $283 \pm 19^{\mathrm{AB}}$ & $290 \pm 16^{\mathrm{AB}}$ & $283 \pm 13^{\mathrm{AB}}$ & $278 \pm 25^{\mathrm{AB}}$ & $301 \pm 18^{\mathrm{B}}$ \\
\hline
\end{tabular}

The data are presented as the mean \pm SD. The values in the same row that do not share the same superscript letter are significantly different (analysis of variance, $P<0.05)$

$F F$ a fiber-free diet, $C E L$ a diet with $5 \%$ cellulose, $P E C$ a diet with $5 \%$ pectin, $C E L+P E C$ a diet with $2.5 \%$ cellulose and $2.5 \%$ pectin, $W M$ wet mass

${ }^{\mathrm{a}}$ The diets differ in fiber content and $\mathrm{Cr}$ content

\section{Discussion}

The interactive effect of fiber and $\mathrm{Cr}$ on mineral distribution in the body has not yet been established. Therefore, studies on the effects of $\mathrm{CrCl}_{3}$ intake for a short time ( 6 weeks), at the level of $2.53 \mathrm{mg}$ elemental $\mathrm{Cr} / \mathrm{kg} \operatorname{diet}(250 \%$ of the amount applied to the standard diet for laboratory rodents), were undertaken in rats fed diets with and without pectin and cellulose. The effects were also assessed in rats fed diets with or without fiber containing a low level of $\mathrm{Cr}(0.164 \mathrm{mg} / \mathrm{kg}$ diet), originating naturally from the components of the diet. This low level of $\mathrm{Cr}$ in the diet was considered sufficient for rats, as it has been shown that $\mathrm{Cr}$ at a tenfold lower level $(0.016 \mathrm{mg} / \mathrm{kg}$ diet $)$ did not negatively influence the rat

Table 4 The effects of experimental diets on the $\mathrm{Cr}, \mathrm{Ca}, \mathrm{Fe}, \mathrm{Zn}$, and $\mathrm{Mg}$ content in the livers and kidneys of rats

\begin{tabular}{|c|c|c|c|c|c|c|c|c|}
\hline \multirow[t]{2}{*}{ Mineral } & \multicolumn{8}{|c|}{ Experimental diets $^{\mathrm{a}}$} \\
\hline & $\mathrm{FF}$ & $\mathrm{FF}+\mathrm{Cr}$ & CEL & $\mathrm{CEL}+\mathrm{Cr}$ & PEC & $\mathrm{PEC}+\mathrm{Cr}$ & $\mathrm{CEL}+\mathrm{PEC}$ & $\mathrm{CEL}+\mathrm{PEC}+\mathrm{Cr}$ \\
\hline \multicolumn{9}{|l|}{ Liver } \\
\hline $\mathrm{Cr}(\mu \mathrm{g} / \mathrm{g} \mathrm{WM}) \times 10^{-2}$ & $3.31 \pm 2.51^{\mathrm{A}}$ & $5.51 \pm 2.19^{\mathrm{AB}}$ & $3.27 \pm 1.85^{\mathrm{A}}$ & $4.51 \pm 2.93^{\mathrm{A}}$ & $3.95 \pm 2.46^{\mathrm{A}}$ & $30.5 \pm 10.8^{\mathrm{B}}$ & $4.20 \pm 1.94^{\mathrm{AB}}$ & $3.03 \pm 1.66^{\mathrm{AB}}$ \\
\hline $\mathrm{Ca}(\mu \mathrm{g} / \mathrm{g} \mathrm{WM})$ & $44.1 \pm 13.0^{\mathrm{A}}$ & $54.4 \pm 11.3^{\mathrm{AB}}$ & $56.8 \pm 18.3^{\mathrm{AB}}$ & $47.8 \pm 9.8^{\mathrm{A}}$ & $42.7 \pm 8.2^{\mathrm{A}}$ & $57.7 \pm 16.8^{\mathrm{AB}}$ & $56.1 \pm 16.8^{\mathrm{AB}}$ & $69.0 \pm 12.4^{\mathrm{B}}$ \\
\hline $\mathrm{Fe}(\mu \mathrm{g} / \mathrm{g} \mathrm{WM})$ & $104.0 \pm 15.3$ & $85.9 \pm 15.6$ & $87.5 \pm 9.2$ & $90.3 \pm 8.0$ & $90.6 \pm 10.8$ & $101.0 \pm 22.5$ & $93.5 \pm 11.3$ & $102.1 \pm 8.2$ \\
\hline $\mathrm{Zn}(\mu \mathrm{g} / \mathrm{g} W M)$ & $37.0 \pm 3.2^{\mathrm{A}}$ & $33.1 \pm 2.9^{\mathrm{AB}}$ & $35.0 \pm 3.3^{\mathrm{AB}}$ & $35.7 \pm 1.1^{\mathrm{A}}$ & $29.6 \pm 3.0^{\mathrm{B}}$ & $34.5 \pm 4.6^{\mathrm{AB}}$ & $32.6 \pm 2.9^{\mathrm{AB}}$ & $33.5 \pm 1.9^{\mathrm{AB}}$ \\
\hline $\mathrm{Mg}(\mu \mathrm{g} / \mathrm{g} \mathrm{WM})$ & $237 \pm 28^{\mathrm{A}}$ & $217 \pm 12^{\mathrm{AB}}$ & $215 \pm 21^{\mathrm{AB}}$ & $209 \pm 17^{\mathrm{AB}}$ & $184 \pm 17^{\mathrm{B}}$ & $231 \pm 30^{\mathrm{A}}$ & $211 \pm 30^{\mathrm{AB}}$ & $221 \pm 15^{\mathrm{A}}$ \\
\hline \multicolumn{9}{|l|}{ Kidney } \\
\hline $\mathrm{Cr}(\mu \mathrm{g} / \mathrm{g} \mathrm{WM}) \times 10^{-2}$ & $2.73 \pm 1.73$ & $2.67 \pm 1.61$ & $3.43 \pm 1.85$ & $2.19 \pm 0.66$ & $2.44 \pm 1.24$ & $2.78 \pm 0.71$ & $2.83 \pm 1.25$ & $3.65 \pm 2.54$ \\
\hline $\mathrm{Ca}(\mu \mathrm{g} / \mathrm{g} \mathrm{WM})$ & $49.5 \pm 13.5^{\mathrm{AB}}$ & $37.8 \pm 7.2^{\mathrm{A}}$ & $61.3 \pm 9.8^{\mathrm{B}}$ & $55.6 \pm 18.2^{\mathrm{AB}}$ & $53.5 \pm 16.2^{\mathrm{AB}}$ & $54.5 \pm 10.0^{\mathrm{AB}}$ & $38.4 \pm 5.8^{\mathrm{A}}$ & $43.4 \pm 11.3^{\mathrm{AB}}$ \\
\hline $\mathrm{Fe}(\mu \mathrm{g} / \mathrm{g} \mathrm{WM})$ & $46.2 \pm 7.2$ & $40.7 \pm 9.3$ & $42.2 \pm 5.2$ & $44.5 \pm 10.1$ & $44.5 \pm 5.0$ & $50.0 \pm 9.8$ & $41.1 \pm 7.6$ & $41.5 \pm 7.4$ \\
\hline $\mathrm{Zn}(\mu \mathrm{g} / \mathrm{g} W M)$ & $19.5 \pm 1.9^{\mathrm{AC}}$ & $19.7 \pm 2.3^{\mathrm{AC}}$ & $22.5 \pm 1.6^{\mathrm{BD}}$ & $23.7 \pm 2.6^{\mathrm{B}}$ & $22.5 \pm 1.3^{\mathrm{BD}}$ & $24.7 \pm 1.6^{\mathrm{B}}$ & $20.2 \pm 1.2^{\mathrm{CD}}$ & $20.4 \pm 1.8^{\mathrm{CD}}$ \\
\hline $\mathrm{Mg}(\mu \mathrm{g} / \mathrm{g} W M)$ & $165 \pm 16^{\mathrm{AC}}$ & $158 \pm 9^{\mathrm{A}}$ & $191 \pm 17^{\mathrm{BC}}$ & $185 \pm 20^{\mathrm{AB}}$ & $196 \pm 12^{\mathrm{B}}$ & $195 \pm 19^{\mathrm{BC}}$ & $172 \pm 13^{\mathrm{AB}}$ & $192 \pm 29^{\mathrm{BC}}$ \\
\hline
\end{tabular}

The data are presented as the mean $\pm \mathrm{SD}$. The values in the same row that do not share the same superscript letter are significantly different (analysis of variance, $P<0.05)$

$F F$ a fiber-free diet, $C E L$ a diet with $5 \%$ cellulose, $P E C$ a diet with $5 \%$ pectin, $C E L+P E C$ a diet with $2.5 \%$ cellulose and $2.5 \%$ pectin, $W M$ wet mass

${ }^{\mathrm{a}}$ The diets differ in fiber content and $\mathrm{Cr}$ content 
organism, at least it did not affect the body composition or glucose metabolism of male Zucker rats [24]. In this study, the urinary $\mathrm{Cr}$ excretion rate in $\mathrm{Cr}$-supplemented rats ranged from 0.07 to $0.25 \%$; in rats fed low-Cr diets, urinary excretion rate ranged from 1.01 to $2.73 \%$, and the highest value was obtained in rat group fed CEL+PEC diet (Table 2). The influence of dietary fiber on $\mathrm{Cr}$ loss has not yet been evaluated. However, the results obtained in this work may suggest the promotive effect of fiber on urinary $\mathrm{Cr}$ excretion.

The mean $\mathrm{Cr}$ content in the tissues of the experimental rats was highest in the thigh muscles, followed by the femur, the liver, and the kidneys. Cr supplementation (in the form of $\mathrm{CrCl}_{3}$ ) of the fiber-free diet containing $62 \%$ wheat starch had no effect on $\mathrm{Cr}$ distribution in the tissues of the rats in comparison with the group fed a FF diet without $\mathrm{Cr}$. In contrast to these findings, Anderson et al. [4] showed that in rats fed diets containing $63 \%$ cornstarch supplemented with different compounds of $\mathrm{Cr}$ (III) that provided $5 \mathrm{mg}$ elemental $\mathrm{Cr} / \mathrm{kg}$ diet, the concentration of $\mathrm{Cr}$ in the kidneys was more than ten times higher than in other tissues. In the rats that received a diet with $\mathrm{CrCl}_{3}$, these authors found that the $\mathrm{Cr}$ content was highest in the kidneys, followed by the lungs, the gastrocnemius muscle, the liver, the spleen, and the heart.

In the present study, $\mathrm{Cr}$ supplementation of a diet including cellulose and/or pectin led to a higher $\mathrm{Cr}$ and $\mathrm{Fe}$ content in the femurs of rats. The increased concentration of $\mathrm{Fe}$ in bone as a result of $\mathrm{Cr}$ and fiber supplementation may have a potentially beneficial effect. Research conducted by Katsumata et al. [25] demonstrated the role of $\mathrm{Fe}$ in maintaining bone mineral density and the mechanical strength of the femur in rats. The role of $\mathrm{Cr}$ in the metabolism of bone tissue is poorly understood. It may be related to the anabolic action of insulin. $\mathrm{CrPic}_{3}$ has been found to reduce the urinary excretion of hydroxyproline and $\mathrm{Ca}$ in postmenopausal women, presumably indicating a reduced rate of bone resorption [26].

In this study, it was observed that adding cellulose and pectin to the diets with $\mathrm{Cr}$ promoted lower concentrations of $\mathrm{Ca}$ and $\mathrm{Fe}$ in skeletal muscle. Chronically low levels of $\mathrm{Ca}$ may have a negative impact on muscle contractility [27], while lower Fe reserves may disturb oxygen homeostasis and potentiate erythropoiesis [28].

It was also shown in this study that the $\mathrm{Cr}$ content and the $\mathrm{Ca}$ content in the liver were very sensitive to supplemental $\mathrm{Cr}$ when given together with pectin or pectin and cellulose, respectively. Other studies have demonstrated an increase in the $\mathrm{Cr}$ concentration in the livers of rats [4] and pigs [5] fed a diet supplemented with $\mathrm{CrPic}_{3}$. The influence of supplemental pectin and Cr given in the form of $\mathrm{CrCl}_{3}$ on accumulation of minerals in rat tissues has not yet been examined, so the obtained results could not be compared with published data. The extremely high level of $\mathrm{Cr}$ in liver resulting from feeding rats $\mathrm{PEC}+\mathrm{Cr}$ diet was rather unexpected. Pectin was shown to either prevent or has no influence on metal accumulation in rat tissues. The binding of metal ions to pectin has been demonstrated, which depends on type of pectin as well as metal ion. The effect of pectin was studied mainly for bivalent metals, not for trivalent ones [29, 30]. Acetic acid (the main product of pectin fermentation in lumen) and $\mathrm{Cr}$ have been shown to lower blood insulin level [31-33]. As presented in the previous work, a lowering effect on the plasma insulin level of rats was only observed in the $\mathrm{Cr}$ supplemented group that was fed a diet without fiber-however, adding pectin to the $\mathrm{Cr}$-supplemented diet significantly increased the concentration of insulin [19]. These contradictory effects may be the results of metabolic disturbances related to a high-fat diet which could hide the beneficial effects of chromium and pectin. In a study conducted by Król et al. [34], the administration of a high-fat diet with a standard level of fiber $(5 \%$ cellulose) also led to increased insulin level in serum of rats whether supplemented with $\mathrm{Cr}$ propionate or not (supplementation levels 10 or $50 \mathrm{mg} \mathrm{Cr} / \mathrm{kg}$ diet). Increased insulin concentration in blood has been shown to decrease the circulating $\mathrm{Cr}$ level, as the metal is taken up by insulin-dependent cells via LMWCr formation [35]. The liver is an insulin-sensitive organ, and therefore, supplemental $\mathrm{Cr}$ could accumulate in hepatic cells as a consequence of metabolic disturbances.

The results of the present study indicate that the balance of minerals in the kidneys may depend on the type of fiber consumed. According to many studies on rats and other healthy laboratory animals [4, 7, 36], as well as diabetic animals [37], kidney tissue is the most sensitive tissue (or one of the most highly sensitive tissues) to supplemental $\mathrm{Cr}$, although this effect was not shown in the present study. It is not possible to determine the reason for this inconsistency, given the differences in the time of administration, the dosages, the chemical forms of $\mathrm{Cr}$, and the metabolic conditions of the rats.

The observed alterations in tissue mineral distribution might be the results of several mechanisms. Minerals may be bound by dietary fiber, thus decreasing their bioavailability; this mainly concerns insoluble dietary fiber (cellulose) and, as noted in several studies, phytate content mainly potentiated this effect [38]. Except for $\mathrm{Zn}$ concentration in the femur, a generally decreased mineral accumulation in rat groups fed diets with purified cellulose was not observed. Rats fed diets supplemented with pectin may absorb more minerals due to the positive influence of carbohydrate fermentation by gut microflora and increased cecum weight [39]. This effect was observed only on $\mathrm{Zn}$ and $\mathrm{Mg}$ accumulation in the kidneys and, in rats supplemented with $\mathrm{Cr}$ and pectin, on $\mathrm{Cr}$ level in the liver. This ambiguous influence of soluble fiber on mineral accumulation might be the result of the use of a standard dose of pectin in this study (5\%). In the study by Krejpcio et al. [40], no less than $10 \%$ of soluble fiber (oligofructans) resulted in $\mathrm{Mg}$ accumulation in rat bones.

Changes in dietary $\mathrm{Cr}$ content could also affect mineral distribution, as shown in several earlier studies [7, 8, 41]. $\mathrm{Cr}$ is noted as affecting Fe metabolism mainly through the common 
transport protein transferrin [42], although no decreased accumulation of $\mathrm{Fe}$ was observed in rats supplemented with $\mathrm{Cr}$. Adding PEC to diets supplemented with $\mathrm{Cr}$ even improved femur accumulation in rats. Clodfelder et al. [43] did not observe a decrease in Fe levels in kidney and liver tissue from different models of rats either, although there was a trend towards higher Fe kidney accumulation in Sprague Dowley and ZDF rats after Cr supplementation. On the other hand, in a study conducted by Sun et al. [44], the different effects of $\mathrm{Cr}$ on Fe metabolism were the result of the chemical form of $\mathrm{Cr}$. Administration of $\left[\mathrm{Cr}_{3} \mathrm{O}\left(\mathrm{O}_{2} \mathrm{CCH}_{2} \mathrm{CH}_{3}\right)_{6}\left(\mathrm{H}_{2} \mathrm{O}\right)_{3}\right]^{+}$did not affect $\mathrm{Fe}$ concentration in the liver tissue of rats; $\mathrm{LMWCr}$ in the diet led to a decrease in $\mathrm{Fe}$ content. The interaction between $\mathrm{Cr}$ and $\mathrm{Fe}$ and rat metabolism may depend on several factors, e.g., the metabolic conditions of rats and the chemical form and the doses of $\mathrm{Cr}$.

In this study, the addition of different types of dietary fiber that show water-holding capacity might inhibit water absorption in the intestine and apparently increase mineral content in organs, although an unequivocal accumulative effect of dietary fiber on tissue mineral concentration was not observed.

\section{Conclusions}

In conclusion, the results of this study indicate that $\mathrm{Cr}$ (III) at elevated dose and fiber (i.e., cellulose and pectin) in the diet influenced mineral contents in rat tissues. Effects on mineral distribution differed in particular tissues and depended on the type of dietary fiber in the diet. A further study is warranted to investigate the effects of $\mathrm{Cr}$ and fiber ingestion on mineral balance in organism.

Acknowledgments The study was supported by Grant No. 1778 from the Wroclaw Medical University.

Open Access This article is distributed under the terms of the Creative Commons Attribution License which permits any use, distribution, and reproduction in any medium, provided the original author(s) and the source are credited.

\section{References}

1. Anderson RA (1998) Chromium, glucose intolerance and diabetes. J Am Coll Nutr 17:548-555

2. Vincent JB (2004) Recent developments in the biochemistry of chromium (III). Biol Trace Elem Res 99:1-16

3. Hepburn DDD, Vincent JB (2002) In vivo distribution of chromium from chromium picolinate in rats and implications for the safety of the dietary supplement. Chem Res Toxicol 15:93-100

4. Anderson RA, Bryden NA, Polansky MM, Gautschi K (1996) Dietary chromium effects on tissue chromium concentrations and chromium absorption in rats. J Trace Elem Exp Med 9:11-25

5. Lindemann MD, Cromwell GL, Monegue HJ, Purser KW (2008) Effect of chromium source on tissue concentration of chromium in pigs. J Anim Sci 86:2971-2978
6. Şahin K, Şahin N, Güler T, Ertaş ON (2001) The effect of supplemental dietary chromium on performance, some blood parameters and tissue chromium contents of rabbits. Turk J Vet Anim Sci 25: 217-221

7. Chang X, Mowat DN, Spiers GA (1992) Carcass characteristics and tissue-mineral contents of steers fed supplemental chromium. Can J Anim Sci 72:663-668

8. Staniek H, Rhodes NR, Di Bona KR, Deng G, Love ST, Pledger LA, Blount J, Gomberg E, Grappe F, Cernosek C, Peoples B, Rasco JF, Krejpcio Z, Vincent JB (2013) Comparison of tissue metal concentrations in Zucker lean, Zucker obese, and Zucker diabetic fatty rats and the effects of chromium supplementation on tissue metal concentrations. Biol Trace Elem Res 151:373-383

9. Yoshida M, Hatakeyama E, Hosomi R, Kanda S, Nishiyama T, Fukunaga K (2010) Tissue accumulation and urinary excretion of chromium in rats fed diets containing graded levels of chromium chloride or chromium picolinate. J Toxicol Sci 35:4854-4891

10. Chawla R, Patil GR (2010) Soluble dietary fiber. Compr Rev Food Sci Food Saf 9:178-196

11. Weickert MO, Pfeiffer AFH (2008) Metabolic effects of dietary fiber consumption and prevention of diabetes. J Nutr 138:439-442

12. Greger JL (1999) Nondigestible carbohydrates and mineral bioavailability. J Nutr 129:1434S-1435S

13. El-Zoghbi M, Sitohy MZ (2001) Mineral absorption by albino rats as affected by some types of dietary pectins with different degrees of esterification. Nahrung/Food 45:114-117

14. Ismail-Beigi F, Reinhold JG, Faraji B, Abadi P (1977) Effects of cellulose added to diets of low and high fiber content upon metabolism of calcium, magnesium, zinc and phosphorus by man. J Nutr 107:510-517

15. Hara H, Nagata M, Ohta A, Kasai T (1996) Increases in calcium absorption with ingestion of soluble dietary fibre, guar-gum hydrolysate, depend on the caecum in partially nephrectomized and normal rats. Br J Nutr 76:773-784

16. Younes H, Demigne C, Remesy C (1996) Acidic fermentation in the caecum increases absorption of calcium and magnesium in the large intestine of the rat. Br J Nutr 75:301-314

17. Coudray C, Bellanger J, Castiglia-Delavaud C, Rémésy C, Vermorel M, Rayssignuier Y (1997) Effect of soluble and partly soluble dietary fibers supplementation on absorption and balance of calcium, magnesium, iron and zinc in healthy young men. Eur J Clin Nutr 51:375-380

18. Reeves PG (1997) Components of the AIN-93 diets as improvements in the AIN-76A diet. J Nutr 127:838S-841S

19. Krzysik M, Grajeta H, Prescha A, Weber R (2011) Effect of cellulose, pectin and chromium(III) on lipid and carbohydrate metabolism in rats. J Trace Elem Med Biol 25:97-102

20. Juturu V, Komorowski JR, Devine JP, Capen A (2003) Absorption and excretion of chromium from orally administered chromium chloride, chromium acetate and chromium oxide in rats. Trace Elem Electrolytes 20:23-28

21. Pieczyńska J, Prescha A, Weber R, Biernat J, Grajeta H (2011) The effect of cultivation intensity on mineral content in grain, flakes and bran of winter wheat (Triticum aestivum L.) - preliminary study. Rocz Panstw Zakl Hig 62:199-203

22. Krzysik M, Grajeta H, Prescha A (2008) Chromium content in selected convenience and fast foods in Poland. Food Chem 107: 208-212

23. Helrich K (1990) Official methods of analysis. Association of Official Analytical Chemists, 15th edn. AOAC Inc, Arlington VA

24. Di Bona KR, Love S, Rhodes NR, McAdory D, Sinha SH, Kern N, Kent J, Strickland J, Wilson A, Beaird J, Ramage J, Rasco JF, Vincent JB (2011) Chromium is not an essential trace element for mammals: effects of a "low-chromium" diet. J Biol Inorg Chem 16:381-390

25. Katsumata S, Tsuboi R, Uehara M, Suzuki K (2006) Dietary iron deficiency decreases serum osteocalcin concentration and bone mineral density in rats. Biosci Biotechnol Biochem 70:2547-2550 
26. McCarty MF (1995) Anabolic effects of insulin on bone suggest a role for chromium picolinate in preservation of bone density. Med Hypotheses 45:241-246

27. Moe SM (2005) Disorders of calcium, phosphorus, and magnesium. Am J Kidney Dis 45:213-218

28. Robach P, Cairo C, Gelfi C, Bernuzzi F, Pilegaard H, Vigano A, Santambrogi P, Cerretelli P, Calbet JAL, Moutereau S, Lundby C (2007) Strong iron demand during hypoxia-induced erythropoiesis is associated with down-regulation of iron-related proteins and myoglobin in human skeletal muscle. Blood 109:4724-4731

29. Kartel MT, Kupchik LA, Veisov BK (1999) Evaluation of pectin binding of heavy metal ions in aqueous solutions. Chemosphere 38: 2591-2596

30. Serguschenko I, Kolenchenko E, Khotimchenko M (2007) Low esterified pectin accelerates removal of lead ions in rats. Nutr Res 27:633-639

31. Stiffler JS, Law JS, Polansky MM, Bhathena SJ, Anderson RA (1995) Chromium improves insulin response to glucose in rats. Metabolism 44:1314-1320

32. Marounek M, Volek Z, Synytsya A, Copikova J (2007) Effect of pectin and amidated pectin on cholesterol homeostasis and cecal metabolism in rats fed a high-cholesterol diet. Physiol Res 56:433442

33. Fushimi T, Sato Y (2005) Effect of acetic acid feeding on the circadian changes in glycogen and metabolites of glucose and lipid in liver and skeletal muscle of rats. Br J Nutr 94:714719

34. Król E, Krejpcio Z, Iwanik K (2014) Supplementary chromium(III) propionate complex does not protect against insulin resistance in high-fat-fed rats. Biol Trace Elem Res 157:147-155

35. Davis CM, Vincent JB (1997) Chromium in carbohydrate and lipid metabolism. J Biol Inorg Chem 2:675-679
36. Zha LY, Wang MQ, Xu ZR, Gu LY (2007) Efficacy of chromium(III) supplementation on growth, body composition, serum parameters, and tissue chromium in rats. Biol Trace Elem Res 119:42-50

37. Król E, Krejpcio Z (2010) Chromium(III) propionate complex supplementation improves carbohydrate metabolism in insulinresistance rat model. Food Chem Toxicol 48:2791-2796

38. Harrington ME, Flynn A, Cashman KD (2001) Effects of dietary fibre extracts on calcium absorption in the rat. Food Chem 73:263269

39. Scholz-Ahrens KE, Ade P, Marten B, Weber P, Timm W, Yahya GCC, Schrezenmeir J (2007) A prebiotics, probiotics, and synbiotics affect mineral absorption, bone mineral content, and bone structure. $\mathrm{J}$ Nutr 137:838-846

40. Krejpcio Z, Wójciak RW, Staniek H, Wiśniewska J (2009) Effect of dietary supplementation with inulin-type fructans and chromium(III) on magnesium metabolic indices in rat. Zywnosc-Nauka Technologia Jakosc 4:175-182 (in polish)

41. Dogukan A, Sahin N, Tuzcu M, Juturu V, Orhan C, Onderci M, Komorowski J, Sahin K (2009) The effects of chromium histidinate on mineral status of serum and tissue in fat-fed and streptozotocintreated type II diabetic rats. Biol Trace Elem Res 131:124-132

42. Quarles CD Jr, Marcus RK, Brumaghim JL (2011) Competitive binding of $\mathrm{Fe}^{3+}, \mathrm{Cr}^{3+}$, and $\mathrm{Ni}^{2+}$ to transferrin. J Biol Inorg Chem 16:913-921

43. Clodfelder JB, Gullick BM, Lukaski HC, Neggers Y, Vincent JB (2002) Oral administration of the biomimetic $\left[\mathrm{Cr}_{3} \mathrm{O}\left(\mathrm{O}_{2} \mathrm{CCH}_{2} \mathrm{CH}_{3}\right)_{6}\left(\mathrm{H}_{2} \mathrm{O}\right)_{3}\right]^{+}$ increases insulin sensitivity and improves blood plasma variables in healthy and type 2 diabetic rats. J Biol Inorg Chem 10:119-130

44. Sun Y, Mallya K, Ramirez J, Vincent JB (1999) The biomimetic $\left[\mathrm{Cr}_{3} \mathrm{O}\left(\mathrm{O}_{2} \mathrm{CCH}_{2} \mathrm{CH}_{3}\right)_{6}\left(\mathrm{H}_{2} \mathrm{O}\right)_{3}\right]^{+}$decreases cholesterol and triglycerides in rats: towards chromium-containing therapeutics. J Biol Inorg Chem 4:838-845 